\title{
Vegetative Community Diversity Assessment of a Beneficial Use Salt Marsh Restoration
}

Nickolas Murphy

University of Southern Mississippi

Patrick Biber ( $\square$ patrick.biber@usm.edu )

University of Southern Mississippi https://orcid.org/0000-0002-6358-0976

\section{Research Article}

Keywords: Salt marsh, beneficial-use, sediment organic content, diversity, Black needlerush

Posted Date: May 25th, 2021

DOI: https://doi.org/10.21203/rs.3.rs-507079/v1

License: (9) This work is licensed under a Creative Commons Attribution 4.0 International License. Read Full License 
Vegetative Community Diversity Assessment of a Beneficial Use Salt Marsh Restoration

Nickolas R. Murphy (1*), Patrick D. Biber (1+)

4

5 (1) Gulf Coast Research Laboratory, The University of Southern Mississippi. Ocean Springs, MS. U.S.A.

$8 *$ Current address: Environmental Business Specialists, Mandeville, LA

9 + Corresponding author: Patrick.biber@usm.edu

10 ORCID: 0000-0002-6358-0976

\section{ABSTRACT}

13 Restoration of lost marsh platforms can include de-novo construction using dredged sediments.

14 Two restoration projects constructed with beneficial use material in 2004 and 2015 were planted

15 with native vegetation in the anticipation they would function similarly to adjacent Juncus

16 roemerianus (Black needlerush) dominated salt marshes. Planted J. roemerianus, however, failed

17 to establish and exists sparsely in the restored marsh. To better understand potential sources of

18 failure, this study assessed vascular plant diversity in Spring and Fall of 2017 through 2019 and

19 demonstrated establishment of both planted and naturally recruited vegetation. The two

20 constructed sites were found to have higher species richness and plant diversity (Shannon-

21 Wiener H', and Simpson's D) than the natural reference marsh, in part due to the higher

22 elevations of the two constructed sites. The plant diversity metrics indicated the two beneficial

23 use restorations did not meet the species composition of the reference marsh. Further monitoring

24 should be conducted to observe the species development over the long term with considerations

25 given to the potential future marsh change.

26

\section{Key Words}

28 Salt marsh; beneficial-use; sediment organic content; diversity; Black needlerush 


\section{ACKNOWLEDGMENTS}

33 This research was conducted by N. Murphy in the Center for Plant Restoration (CPR) as partial

34 fulfillment of the requirements for the degree of Master of Science at the University of Southern

35 Mississippi. Funding for this research was provided through a grant from the U.S. Army

36 Engineer Research and Development Center (W912HZ-16-SOI-0033) to P. Biber. We thank J.

37 Kelly at 3-Point Eco-logical LLC for vessel and field sampling support.

\section{DECLARATIONS}

40 Funding - This study was funded by cooperative agreement W912HZ-16-SOI-0033 from the

41 U.S. Army Corps of Engineers Research and Development Center (ERDC) to P. Biber under the 42 terms of the Gulf Coast Cooperative Ecosystems Studies Unit (CESU). Views, opinions, and/or

43 findings contained herein are those of the authors and should not be construed as an Official

44 Department of the Army position or decision unless so designated by other official

45 documentation

46 Conflicts of interest/Competing interests - The authors declare that the research was

47 conducted in the absence of any commercial or financial relationships that could be construed as 48 a potential conflict of interest

49 Availability of data and material - Data are freely available in Murphy (2020), and/or upon

50 request to the corresponding author on reasonable request (Patrick.biber@usm.edu).

51 Code availability - Not applicable

52 Authors' contributions - NM and PB contributed to the study conception and design. Material

53 preparation, data collection and analysis were performed by NM who then wrote the thesis on

54 which this manuscript is based. PB edited and updated the relevant portions of that thesis to

55 create this manuscript. All authors read and approved the final manuscript.

56 Ethics approval - The authors declare that sampling was conducted with all appropriate permits

57 and consent, including MDMR Scientific Research permit \#SRP-005A-17

58 Consent to participate - Not applicable

59 Consent for publication - Not applicable

60

61 
Coastal wetland losses from anthropogenic impacts are widespread due to altered sediment supply and hydrology, coastal development, and recently climate change and accelerated sea level rise and frequency of large storm events (Turner 1990, 1997; Herbert et al. 2016; Wu et al. 2017, 2020). Salt marshes in the U.S. are expected to be reduced by $20-45 \%$ by the end of the $21^{\text {st }}$ century, and in the northern Gulf of Mexico (GoM), wetland loss is rampant (Stedman and Dahl 2008; Engle 2011; Kirwan and Megonigal 2013). To offset these losses, construction of coastal wetlands in the United States began in the late $20^{\text {th }}$ century and has become more prominent today as a management action. Restoration of coastal wetlands in the northern GoM can include de-novo construction of lost marsh platforms using fill or dredged sediments, thin-layer placement in existing marsh platforms, or construction of dredged material islands and cheniers that form a localized sediment source over time. Depending on the desired habitat, restoration project managers can opt to either plant the newly placed material with target vegetation or allow the site to be naturally colonized (Mitsch and Wilson 1996; Zedler and Callaway 1999, 2000; Craft et al. 2002, 2003; Herbert et al. 2016).

Many salt marsh distribution studies have highlighted the role of elevation in wetland restoration (Eleuterius and Eleuterius 1979; Woerner and Hackney 1997; Bockelmann et al. 2002; Silvestri et al. 2005). Planting density depends on how the risks of physical stress compare to stress from competition. In coastal wetlands, where the plants will experience wave impacts, it can be important for managers to consider increased planting density so that plants can facilitate the growth of other individuals through positive interactions (Silliman et al. 2015). Although the starting material for transplanting salt marsh vegetation varies among species, bareroot plants are appropriate for transplanting most grasses (USDA 2010). Physical sediment characteristics such as texture, porosity, and bulk density can affect the aeration of the rhizosphere and thereby influence rhizobacteria and root growth (Mendelssohn and Morris 2002; Mavrodi et al. 2018). Fertilizers, which add inorganic $\mathrm{N}$ and $\mathrm{P}$, are often applied and can shorten the period between planting and successful establishment of transplanted vegetation (Broome et al. 1988). The speed at which vegetation diversity and standing stock biomass change post-construction varies among projects and depends on successional processes (Cammen 1975; Earhart and Garbish. 1983;

91 Webb and Newling 1984; Zedler and Callaway 1999; Craft et al. 2002, 2003; Herbert et al. 2016; 92 Ebbets et al. 2019). 
Restoration success of a constructed wetland is intertwined with the succession of species

94 resulting in differences in diversity over time (Luken 1990; Mossman et al. 2012). Restored

95 marsh characteristics such as vegetation coverage and plant species richness, can vary with

96 geomorphic position, tidal range, salinity, and soil classification (Craft et al. 2003). Plant

97 coverage of restored marshes can develop to reference levels as quickly as one year when

98 planted with vegetation, or can take up to five years if a site is left to naturally recruit plant

99 species (Walker et al. 2007).-Species succession within salt marshes is driven by 1) competition

100 among plant species within the middle and high marsh zones (Johnson 1997), 2) storm events

101 which can displace diverse communities and enable invasive species to take hold (Garbutt and

102 Wolters 2008), and 3) conversion of high marsh to low marsh due to sediment compaction,

103 subsidence, and relative SLR (Choi et al. 2001). Community composition in successfully

104 restored marshes should have similar diversity to a reference site, however, succession can be

105 delayed by disturbances such as tropical storms and hurricanes. The path of succession in a

106 restored salt marsh is sometimes used as an indicator of the marshes progress towards reference

107 site conditions (Petchey and Gaston 2006; Almeida et al. 2016; Taddeo and Dronova 2018).

108 Coastal restoration in the United States has generally targeted Spartina alterniflora

109 Loisel. (Smooth cordgrass) dominated marshes in Texas, Louisiana, and along much of the

110 Atlantic coast (Webb and Newling 1984; LaSalle et al. 1991; Taniguchi 1996; Zedler and

111 Callaway 1999). Restoration projects that assess vegetation diversity trends in constructed

112 Spartina-dominated marshes have, therefore, been well explored in the past (Woodhouse 1979;

113 Webb and Newling 1984; LaSalle et al. 1991; Taniguchi 1996; Zedler 2000; Craft et al. 2002;

114 Lang 2012). However, reports from restored Juncus roemerianus Scheele (Black needlerush)

115 dominated marshes, in particular in the northern GoM, are under-reported and thus there are

116 relatively few assessments of marsh restoration with this species (LaSalle 1996; Lang 2012;

117 Sparks et al. 2013, 2015). Effective criteria for assessing constructed wetlands often include

118 collecting data concerning plant community diversity and then comparing them to a natural

119 reference site over time (Zedler and Callaway 2000).

120 This manuscript is among the first studies documenting the restoration progress of

121 Juncus-dominated marshes at two beneficial use sites. Assessment of the vegetation community

122 composition of these two restored sites was compared against an adjacent natural reference

123 marsh using a space for time substitution with three objectives: 
124 1) Understand potential drivers of plant community composition and development by measuring 125 site elevations.

126 2) Assess the success of planted vegetation versus natural recruitment by inventorying the plant

127 community and comparing vegetation diversity among sites.

128 3) Determine the successional trajectory of the constructed sites towards the natural marsh community by comparing species diversity change over time.

\section{MATERIALS AND METHODS}

\section{Study sites}

This study took place on two constructed sites of differing ages and a natural reference marsh on Deer Island, Mississippi (MS). Deer Island Multi-Year Restoration (DIMR) 1 and DIMR2 were constructed in 2004 and 2015, respectively, on the northeastern shore of Deer Island, MS (Figure 1). The constructed sites, DIMR1 and DIMR2, are adjacent to each other and joined by a sand containment dike that protects the inner developing marsh platforms from

138 erosion. At both sites a shallow sandy containment berm was constructed and filled with

139 beneficial use materials from the maintenance dredging placed at numerous discharge locations

140 within the containment area to create variation in the finished elevation and habitat diversity

141 (Roth et al. 2012). The western end of the containment berm was initially left open to promote

142 circulation but subsequently filled in over time.

143 The 2+ year constructed site, DIMR2 is a 16-hectare area constructed from 2015 to 2018

144 with sediments dredged from multiple sources in Jackson and Harrison Counties in Mississippi.

145 The eastern third of the DIMR2 site was planted in spring 2016 with commercially purchased $J$.

146 roemerianus (18,836 plants) and S. alterniflora (18,836 plants) in the interior high and low

147 marsh zones. On the exterior containment dike, Spartina patens (Aiton) Muhl. (saltmarsh hay -

148 2,041 plants), Panicum amarum Elliott (bitter panicgrass - 2,041 plants), and Uniola paniculata

149 L. (seaoats - 4,083 plants) (Biber 2020). Additional revegetation of the remainder of this site has 150 occurred largely through natural recruitment since then.

151 The 10+ year constructed site, DIMR1, was constructed in 2004 with dredged sediments 152 sourced from Biloxi Bay channel and is 18 hectares in size (MDMR 2010; Gerhardt Smith et al. $1532015)$ and is highlighted as a successful example of the Engineering with Nature ${ }^{\mathrm{TM}}$ (EWN)

154 program by the U.S. Army Corps of Engineers. The 10+ yr constructed site was first planted in 
155 spring 2005 with field harvested J. roemerianus (13,440 plants), commercially purchased $S$.

156 alterniflora (15,400 plants) and S. patens (17,920 plants) within the containment dike. Following

157 extensive dike failure during and after hurricane Katrina (Aug 2005), additional sediments and a

158 more expansive containment feature was constructed during 2010-2011 (Lang 2012; Roth et al.

159 2012). Further planting of J. roemerianus, S. alterniflora, S. patens, P. amarum, and $U$.

160 paniculata was periodically completed at the 10+ yr constructed site from 2008-2011, with the

161 most substantial planting being of 15,000 J. roemerianus, 5,000 S. alterniflora and 3,000 dune

162 plants in 2008 (Biber 2011), with natural recruitment of vegetation since then. It should be noted

163 that the age of the $10+\mathrm{yr}$ constructed site could potentially be misleading due to the periodic

164 sediment renourishment and supplemental plantings over the past 10+ years to address ongoing

165 erosion problems.

The 100+ year reference marsh is approx. $500 \mathrm{~m}$ from the $2+\mathrm{yr}$ and $10+\mathrm{yr}$ constructed

167 sites, separated by an upland dune ridge colonized by Pinus palustris Mill. (longleaf pine) and a

168 variety of shrubs such as Serenoa repens W. Bartram (small saw palmetto), and Baccharis

169 halimifolia L. (eastern baccharis). The natural marsh is entirely comprised of a zone mixed with

170 J. roemerianus and S. alterniflora, with mussels and fiddler crab burrows frequently found in the

171 soft, muddy sediment (Peterson et al. 2007; Wright et al. 2013).

172 Field sampling and elevation

173 Sampling was conducted over six seasons: spring and fall 2017, spring and fall 2018, and 174 spring and fall 2019 (Table 1). During the initial spring 2017 sampling season, two $100 \mathrm{~m}$ long

175 replicate transects were established at each study site with approximately $250 \mathrm{~m}$ between starting

176 points. In the fall 2017 sampling season and onward, an additional $100 \mathrm{~m}$ replicate transect was

177 added in the middle of the original two transects for improved sampling of community diversity

178 using the point-intersect method, resulting in $125 \mathrm{~m}$ between transects. Starting points at the $2+$

$179 \mathrm{yr}$ and 10+ yr constructed sites were established randomly along the containment dike which lies

180 on the northern part of the site; at the 100+ yr site the starting point was located at the mid to

181 high marsh transition (Figure 1). The starting points were retained across all sampling seasons.

182 At each sampling effort, the transects were ran from the starting point, generally in the same

183 compass direction, resulting in similar transect orientations with different ending points across

184 each sampling season. 
Finally, for collection of high-resolution site-specific elevation data, one-hundred and

186 sixty-five discrete elevation points were measured by a Real Time Kinematic GPS (Trimble R8)

187 in April 2017 and August 2018 (Table 1) and converted to an elevation contour map (Spheroid:

188 GRS_1980, Coordinate system: GCS_North_American_1983) in ArcGIS (Esri, Redlands, CA).

189 Elevation data points were interpolated with Universal Kriging using the 3D analyst toolbox in

190 ArcMAP (ver. 10.4.1) with no transformation and constant trend removal. Tidal range in the

191 region is between 0.3 and $0.6 \mathrm{~m}$ with a single high and low tide in a $24 \mathrm{hr}$ time span. The natural

192 sites was regularly inundated at high tide, whereas the two restored sites had limited tidal

193 exchange and are mostly groundwater fed. Salinities range from brackish to 25 ppt depending on

194 season and freshwater inputs.

195

\section{Vegetation diversity and percent cover}

197 In five seasons, along the outer two transects, $1 \mathrm{~m}^{2}$ quadrats were used to estimate percent

198 cover of plant species (Table 1). Quadrats were spaced haphazardly at approximately 20-40 m

199 intervals and placed within representative areas of each marsh zone (low-, mid-, high-marsh, and

200 dunes). The percent cover of the three most abundant species in the $1 \mathrm{~m}^{2}$ quadrat was estimated

201 visually by a minimum of two personnel experienced in identifying plants that occur in the

202 northern GoM. To obtain additional resolution on along transect vegetation diversity and plant

203 species richness estimates the Point-Intercept method described in Caratti (2006), was employed

204 along all three transects at $1 \mathrm{~m}$ intervals for the fall 2017, spring 2018, fall 2018, and spring 2019

205 sampling seasons (Table 1). For any unidentified plants in either the quadrat-based or point-

206 intercept sampling, one or more voucher specimens were returned to the laboratory for

207 identification using appropriate field guides (Correll and Johnston 1970; Radford et al. 1983;

208 Clewell 1985).

209 Point-Intercept and quadrat-based percent cover observations were used to calculate

210 separate measurements of relative percent cover of each plant species observed. Percent cover

211 was estimated from point-intercept transects by taking the total number of observations of a

212 species along a transect and dividing it by the total number of observations of all species along

213 the transect. The two independent percent cover estimates were then used for calculating species

214 richness, alpha- and beta-diversity, respectively for each site and season. Transects were grouped

215 by site and percent cover estimated by the point-intercept method and used to calculate the 
216 Shannon-Wiener Index of Diversity (Eq. 1) and Simpson's Index of Diversity (Eq. 2) to assess

217 the species richness and evenness as estimates of alpha diversity for each site. A Bray-Curtis

218 index of dissimilarity (Eq. 3) was created using percent cover from the quadrat-based samples to

219 estimate the beta diversity across sites.

$$
H^{\prime}=-\sum_{i=1}^{S} p_{i} \ln p_{i}
$$

222 Equation 1. Derived equation for Shannon-Wiener Index of Diversity. The index of diversity if $223 H^{\prime}, S$ is species richness, and $p \mathrm{i}$ is the relative proportion of each species within the community 224 (Peet 1974).

$$
D=1-\frac{\sum_{i=1}^{S} n_{i}\left(n_{i}-1\right)}{N(N-1)}
$$

227 Equation 2. Simpson's Index of Diversity where $D$ is the diversity index value, $n^{\mathrm{i}}$ is the number 228 of observations of $i^{\text {th }}$ species, and $N$ is total number of all species (Greenberg 1956).

$$
B C_{i j}=1-\frac{2 C_{i j}}{S i_{i}+S_{j}}
$$

231 Equation 3. Bray-Curtis' index of dissimilarity. $\mathrm{C}_{\mathrm{ij}}$ is the sum of the lesser values for only those 232 species in common between quadrats. $S_{i}$ and $S_{j}$ are the total number of species observed at both 233 sites.

\section{Statistical analyses}

All analyses were run in R version 3.5.1 (R Core Team 2018), figures were created using

237 'ggplot2' version 3.1.0 (Wickham 2016). Vegetation diversity analyses using the Bray-Curtis 238 distance matrix, Analysis of Similarity (ANOSIM), and non-metric multidimensional scaling 239 (nMDS) ordination plot were created and performed using 'vegan' version 2.5.3 (Oksanen et al. 240 2018). Vegetative community dissimilarity (distance, $R$ ) among constructed and reference sites 241 was tested with ANOSIM (permutations $=5,000$ ) using a Bray-Curtis dissimilarity matrix 242 created from the quadrat-based cover-observations at $\alpha=0.05$. The dissimilarity matrix was 243 Wisconsin Double standardized and square-root transformed before ordination, following the 
244 guidance in the 'vegan' package (Oksanen et al. 2018). Ordination was done via nMDS and the 245 centroids for each site were plotted with one standard deviation ellipses to allow for inferences 246 on whether differences exist among sites.

247 Indicator species analysis was performed using 'indicspecies' version 1.7.6 (Caceres and 248 Legendre 2009) to gain insight on how elevation may play a role in the vegetative assemblage of 249 the constructed and reference sites. The analysis was performed separately for each site by 250 partitioning the sites into elevation ranges. Elevation ranges were estimated from the kriging 251 performed on the elevation data and were coded as being either Low- (0.0 - 0.54 MAMSL), 252 Mid- (0.54 - 0.76 MAMSL), or High-marsh (> 0.76 MAMSL) following the classifications of 253 salt marsh elevation zones by Eleuterius and Eleuterius (1979). The indicator species analysis 254 tested the hypothesis that the observed indicator value for each species is no different from the 255 indicator value generated through random permutations $(\alpha=0.05)$. Finally, one-way analysis of 256 variance (ANOVA) was used to test for any significant $(p<0.05)$ difference in the mean 257 elevation of each site, which may have contributed to any differences found in plant community 258 assemblages.

\section{RESULTS}

\section{Elevation}

The $10+$ year constructed site had the highest mean elevation at 0.76 meters above mean sea level (MAMSL) and widest range of 0.80 MAMSL (Table 2). The 2+ yr constructed site was 264 at an average elevation of 0.54 MAMSL and the narrowest range at 0.35 MAMSL. The constructed sites were both higher than the 100+ yr reference site, which was at an average elevation of 0.27 MAMSL and a range of 0.50 MAMSL (Table 2). A one-way ANOVA showed these mean elevation differences were significant for each site (Table S1).

\section{Vegetation Diversity}

(1) Richness and alpha diversity

272 spring 2019. The 10+ yr constructed site had the highest species richness at $\mathrm{n}=32$. The $2+\mathrm{yr}$

273 constructed site had half the species at $\mathrm{n}=16$. The $100+\mathrm{yr}$ reference marsh had the least number

274 of species at $n=5$. A comprehensive list of species observed from the point-intercept and the 
275 quadrats can be found in Table 3. At the time of sampling, the $2+\mathrm{yr}$ and $10+\mathrm{yr}$ constructed sites 276 were both comprised of a low elevation $S$. alterniflora dominated marsh on the dredge-filled 277 soils and a high marsh zone on the containment berm dominated by the planted S. patens and a 278 variety of naturally recruited vegetation such as D. spicata, B. halimifolia, and Sesbania 279 herbacea (Mill.) McVaugh (Bigpod sesbania). The 100+ yr natural marsh was dominated almost 280 exclusively by S. alterniflora and J. roemerianus. All sites shared commonly found salt marsh 281 plants such as D. spicata, J. roemerianus, S. alterniflora, and S. patens. The two constructed 282 sites uniquely shared species such as the grasses $P$. amarum and Schizachyrium maritimum 283 (Chapm.) Nash (Gulf bluestem). The vine Vigna luteola (Jacq.) Benth (Hairypod cowpea) was 284 also found in the dry, sandy areas of both constructed sites. Ruppia maritima L. (Widgeon grass) 285 was found in a submerged portion of the $2+\mathrm{yr}$ constructed site and an unsampled canal at the $28610+$ yr constructed site. Species unique to the $2+$ yr constructed site were Panicum repens L., 287 Sesuvium portulacastrum (L.) L. (Shoreline seapurslane), and U. paniculata. Notable species 288 unique to the 10+ yr constructed site are B. halimifolia, Hydrocotyle bonariensis Comm. Ex 289 Lam. (Largeleaf pennywort), and Solidago sempervirens L. (Seaside goldenrod). Invasive 290 species were absent at $2+$ yr constructed site and the 100+ yr natural reference marsh, but the 291 invasive Imperata cylindrica (L.) P. Beauv. (Cogon grass) was found at the 10+ yr constructed 292 site, albeit in small amounts (Table 3).

293 The maximum species richness at the $2+\mathrm{yr}$ constructed site was observed at $\mathrm{n}=10$ in 294 Spring 2017 when using quadrat sampling and at $n=15$ in Fall 2018 when using point-intercept 295 sampling (Fig. 2, Table 4). The maximum species richness at the 10+ yr constructed site was 296 observed at $\mathrm{n}=19$ in Spring 2017 when using quadrat sampling and at $\mathrm{n}=25$ in Fall 2018 when 297 using point-intercept sampling (Fig. 2). The maximum species richness at the 100+ yr reference 298 marsh when using quadrat sampling was $n=3$ in Spring 2017, Fall 2017, and Spring 2019 and n $299=5$ during Spring 2019 when using point-intercept sampling (Table 4).

300 Changes in alpha-diversity, Shannon-Wiener H' and Simpson's D, measured at the study 301 sites through the five seasons are similar to the species richness trends (Table 4). When using 302 both quadrat and point-intercept sampling methods, both the 2+ yr and 10+ yr constructed sites 303 had higher diversity than the $100+$ yr reference site (Table 4$)$. The $2+$ yr constructed site had the 304 second highest diversity when using quadrat (Shannon's $H^{\prime}=1.62$, Simpson's D =0.76) and 305 point-intercept (Shannon's $H^{\prime}=1.44$, Simpson's D = 0.59) sampling methods. The $10+\mathrm{yr}$ 
constructed site was the most diverse when using quadrat (Shannon's $H^{\prime}=2.24$, Simpson's D =

307 0.85) and point-intercept (Shannon's $H^{\prime}=2.42$, Simpson's D =0.85) data. Finally, the $100+\mathrm{yr}$

308 reference marsh had the lowest diversity indices when using quadrat (Shannon's $H^{\prime}=1.14$,

309 Simpson's D = 0.67) and point-intercept sampling methods (Shannon's $H^{\prime}=0.85$, Simpson's D $310=0.56)$.

311 The percent cover data at $2+\mathrm{yr}$ constructed site showed a steady development of total

312 vegetative coverage when measured by both quadrat and point-intercept sampling methods. Total

313 vegetative coverage at both the $10+\mathrm{y}$ constructed site and $100+\mathrm{yr}$ reference marsh was

314 relatively consistent over time, regardless of sampling method. Quadrat sampling showed the 2+

$315 \mathrm{yr}$ constructed site increased from 54\% total coverage in Fall 2017 to $86 \%$ total vegetative

316 coverage in Fall 2018 (Fig. 2). Point-intercept sampling similarly showed an increase from 66\%

317 total vegetative coverage in Fall 2017 to 90\% in Fall 2018 (Fig. 2). The 10+ yr constructed

318 varied from 69\% in Spring 2018 to $83 \%$ in Spring 2019 when using quadrat sampling. Point-

319 intercept sampling at the 10+ yr constructed site showed that coverage varied from $80 \%$ in Fall

3202017 to $95 \%$ in Fall 2018. Finally, the 100+ yr reference site ranged from 64\% in Spring 2017 to

$32175 \%$ in Spring 2019 when using quadrat sampling. When using point-intercept sampling the

$322100+$ yr reference marsh ranged from $85 \%$ in Fall 2017 to $97 \%$ in Spring 2019.

(2) Beta-diversity and Indicator Species

325 Beta-diversity across the three sites was quantified by creating a Bray-Curtis dissimilarity 326 matrix from a total of 186 quadrats across all sampling sites and five seasons. The matrix was 327 tested with ANOSIM with the null hypothesis being no distance greater than zero between sites. 328 All site comparisons showed significant beta-diversity among sites (Table S2). The 10+ yr 329 constructed site and the 100+ yr reference marsh were the most dissimilar with an R statistic of

330 0.39. The $2+$ yr constructed site was most similar with the $10+\mathrm{yr}$ constructed site $(R=0.11)$ but 331 was almost as similar with the reference site $(R=0.21)$. To visualize the differences seen in the 332 ANOSIM, the 186 points were plotted in ordination space with nMDS $(\mathrm{k}=2$, stress $=0.08)$. The 333 centroids and 95\% confidence intervals for each site were plotted, and the nMDS reflects the 334 distances measured by ANOSIM (Fig. 3).

335 Indicator analysis was used to observe associations of salt marsh plant species with 336 elevation ranges (low-, mid-, and high-marsh) at the two constructed and natural reference sites. 
As expected, S. alterniflora was associated with low-marsh elevation at each of the three sites

338 (Tables S3 - S5). The association was significant at the $2+\mathrm{yr}(\mathrm{IV}=0.76, p<0.01)$ and $10+\mathrm{yr}$

339 (IV $=0.68, p<0.01)$ constructed sites, however, it was insignificant $(p=0.29)$ at the $100+\mathrm{yr}$

340 reference site despite a high indicator value of 0.95 (upper-bound $=1$ ). This is likely because the

341 marsh platform at the reference site was uniformly low at an average of 0.27 MAMSL, which led

342 to there simply being a low number of permutations where $S$. alterniflora would have been

343 associated with the mid-marsh elevation ranges. J. roemerianus was associated with the low-

344 marsh elevation range at the reference site (IV $=0.79)$, but this association was insignificant ( $p=$

345 0.89). J. roemerianus tended to associate with the 0.54-0.76 MAMSL mid-marsh range at both

346 constructed sites, although the indicator value was low and insignificant in both cases, likely

347 because of the overall low occurrence of J. roemerianus along the sampled transects and

348 constructed sites in general (Tables S3 - S5). There was a similar pattern of S. patens at the 2+ yr

349 constructed where it was significantly associated with the mid-marsh elevation range (IV $=0.59$,

$350 p=0.01$ ), but at the $10+\mathrm{yr}$ constructed site $S$. patens was insignificantly (IV $0.52, p=0.52$ )

351 associated with the mid-marsh elevation range.

\section{DISCUSSION}

Constructed wetlands are becoming more prevalent as humans attempt to offset the loss

354 of these valuable coastal environments. Enhancing coastal wetlands by restoring environments to

355 their natural footprint can lead to regaining ecosystem functions and services, such as water

356 quality improvement, carbon sequestration, storm surge protection, and wildlife habitat. The

357 success of a marsh restoration project should be measured by progress towards goals specifically

358 stated in the restoration management plan associated with the project, however, those goals often

359 have little specificity or a timeline (Zedler and Callaway 2000). This study measured progress of

360 two marshes constructed with beneficial use material in the northern GoM by comparing plant

361 diversity as indicators of site succession and ecosystem developmental.

362 At Deer Island, the elevation and sediment characteristics (Murphy 2020) varied

363 significantly between the constructed and reference sites. The 10+ yr constructed site tended to

364 be higher in elevation and had higher bulk density, higher sand content, and lower sediment

365 organic content than either the $2+$ yr constructed site and the 100+ yr reference marsh (Murphy

366 2020). Salt marsh habitat typically exhibits zonation by elevation, which is influenced by both 

biotic and abiotic factors (Eleuterius and Eleuterius 1979; Packham and Willis 1997; Emery et al. 2001; Bockelmann et al. 2002), thereby influencing species composition. Zonation in northern GoM salt marshes is marked by three distinct vegetation zones described previously by Eleuterius (1972): (1) 0.0 - 0.54 meters above mean sea level (MAMSL) elevation zone dominated by the smooth cordgrass, S. alterniflora, (2) $0.54-0.7$ MAMSL dominated by the black needlerush, J. roemerianus, and (3) zone greater than 0.7 MAMSL with a combination of

373 grasses dominated by salt marsh hay, S. patens and saltgrass, D. spicata, among other

374 herbaceous and even woody plants. These vegetation zones occur along an elevation gradient; at

375 lower elevations waterlogging and saline water inundation exclude most plant species, and

376 higher in the marsh platform abiotic stress is replaced by competition between species for 377 nutrients, space, and light. Alpha- and beta-diversity were measured at the constructed and reference sites from point-intercept and quadrat sample data, respectively. The measurements captured the diversity within specific site and season combinations (alpha diversity) as well as the differences in diversity between sites (beta diversity). Alpha diversity and species richness decline with elevation. The $10+$ yr constructed site had the highest (0.76 MAMSL) and widest range in elevation, and in turn was the most diverse both in terms of species richness $(n=32)$ and two diversity indices. The $2+$ yr constructed site averaged 0.54 MAMSL and had higher species richness $(\mathrm{n}=16)$ and diversity than the $100+\mathrm{yr}$ reference marsh, which was lower in elevation (0.27 MAMSL) and species richness $(n=5)$. The nMDS plot (Fig. 3) illustrates these differences, with points from the two constructed sites showing wide variability, which can be attributed to the higher elevation ranges and resulting increased plant species diversity within those sites in comparison to the lower elevation reference marsh, which had both a tight grouping of points as well as a smaller $95 \%$ confidence ellipse. In terms of position on the nMDS plot, it is 391 also apparent that the 10+ yr constructed site is more different from the 100+ yr reference marsh 392 than it is from the $2+\mathrm{yr}$ constructed site, likely due to the shared dune species observed in the 393 two constructed sites. The location of the 10+ yr constructed site's centroid can probably be 394 attributed to the number of unique species found at that site in the higher elevation dune habitat. 395 The location of the centroid for the $2+\mathrm{yr}$ constructed site could be misleading, however, as there 396 is a high density of points that overlap and lead to the centroid shifting to the right of the plot. 397 This phenomenon can likely be attributed to numerous observations with solely S. alterniflora in 
nearly identical abundances as a result of rapid growth and coalescence after restoration planting in spring 2016.

Relative abundances of species that the sites had in common measured as percent cover using point-intercept sampling were also different. Abundance of S. alterniflora at the $2+\mathrm{yr}$ constructed site $($ cover $=74 \%)$ was more similar to the $100+\mathrm{y}$ reference marsh $($ cover $=61 \%)$ than it was to the $10+\mathrm{yr}$ constructed site $($ cover $=16 \%)$, in part because a much larger portion of the $2+$ yr constructed site and the $100+$ yr reference marsh was below 0.5 MAMSL in the lowmarsh zone most suited for S. alterniflora dominance. Juncus roemerianus, which tends to dominate at mid-marsh elevations, covered $37 \%$ of the $100+$ yr reference marsh but was effectively absent from the two constructed sites for reasons that are not yet fully understood, this despite the 18,836 stems planted at the $2+$ yr constructed site and the 13,440 stems planted at the $10+$ yr constructed site. The high-marsh and dune associated grasses, S. patens and $D$. spicata, were found to cover $40 \%$ and $10 \%$ of the $10+$ yr constructed site, respectively, while

411 less than $10 \%$ of the lower elevation $2+$ yr constructed site was covered by both of these species.

412 It is likely that over time the $2+$ yr constructed site could begin to reach species richness

413 comparable to the $10+$ yr constructed site in the higher elevation zone of the site, as natural 414 recruitment of species can take up to five years (Mitsch and Wilson 1996).

Indicator species analysis was used to assess whether relationships between elevation ranges and salt marsh zonation could be documented in the constructed marshes. Overall the

417 patterns seen between salt marsh species and elevation ranges were as expected from the 418 literature on the northern GoM (Eleuterius 1972; Eleuterius and Eleuterius 1979; Hunter et al. 419 2008), and most deviations from this classical salt marsh zonation were statistically insignificant. 420 The use of indicator species analysis at the 100+ yr reference marsh was uninformative in terms 421 of statistical power, as most of the site is classified by the $0-0.54 \mathrm{~m}$ elevation zone, which 422 impaired the ability of the analysis to compare the observed patterns with the permuted patterns. 423 This analysis could be improved by more extensive sampling of the higher elevation zone that 424 separates the constructed sites from the natural reference marsh. The $2+\mathrm{yr}$ and the $10+\mathrm{yr}$ constructed sites have followed the trajectory of cover in 426 constructed marshes reported in these previous studies (Webb and Newling 1984; LaSalle 1996; 427 Zedler and Callaway 1999, 2000; Craft et al. 2002, 2003; Sparks et al. 2015; Ebbets et al. 2019). 428 Both the $2+$ yr and 10+ yr constructed sites have yet to equilibrate to species diversity 
comparable to the natural reference marsh. The differences in vegetative community assemblage

430 may provide implications for overall floral and faunal biodiversity at the two constructed sites

431 (Streever 2000). The elevation and vegetative composition are likely to influence bird, fish, and

432 invertebrate habitat usage (Weisberg et al. 1981; Burger 2017; Baumann et al. 2018).

433 Furthermore, the construction design of these two beneficial-use sites included a sand berm that

434 fully enclosed the periphery to contain the dredged sediments (Roth et al. 2012). The lack of

435 channels that could allow regular tidal flushing and provide aquatic organisms access to the

436 interior low elevation areas capable of supporting marsh vegetation reduces the potential habitat

437 value. A prior study by Lang (2012) documented groundwater flow across the DIMR1 site

438 originating from the natural marsh to the south and percolating to the northeast following the

439 elevation contours of the original bathymetry prior to site construction. Much of the standing

440 water in the interior of the constructed sites is likely recharged from this groundwater, subsurface

441 hydraulic tidal influence through the coarse sand berm, and rainwater. The salt marsh vegetation

442 composition and distribution at the DIMR1 site was potentially influenced by the lower soil

443 salinity, which has also been noted in other studies (Klijn and Witte 1999; Zedler 2000; Lang

444 2012)

445

CONCLUSIONS

This study provides the first comparative assessment of two adjacent beneficial-use sites

448 of differing ages, which were planted to create Juncus-dominated wetlands representative of

449 northern GoM salt marshes. The post-construction vegetative assessment at the $2+\mathrm{yr}$ and $10+\mathrm{yr}$

450 constructed site has shown mixed success, with $J$. roemerianus mostly absent from the

451 vegetation community. The overall diversity of the plant community is high in the two restored

452 sites compared to the reference site, supporting prior observations that the $2+\mathrm{yr}$ and $10+\mathrm{yr}$

453 constructed sites can support a diverse community of salt marsh flora. The future of salt marsh

454 restoration using beneficial use sediments in the northern GoM is going to require successful

455 colonization of $J$. roemerianus, whether by planting or natural recruitment, as this species is

456 indicative of a natural marsh in this region. 


\section{REFERENCES}

461 Almeida D, Rocha J, Neto C, Arsénio P (2016) Landscape metrics applied to formerly reclaimed saltmarshes: A tool to evaluate ecosystem services? Estuarine, Coastal and Shelf Science 181:100-113.

Baumann M, Fricano G, Fedeli K, Schlemme C, Christman M, Carle M (2018) Recovery of salt marsh invertebrates following habitat restoration: implications for marsh restoration in the Northern Gulf of Mexico. Estuaries and Coasts 43:1711-1721.

Biber P (2011) Deer Island Restoration. https://sites.google.com/view/deer-islandrestoration/home. Accessed 15 Jan 2021

Biber P (2020) Beneficial Use Marsh Restoration. https://sites.google.com/view/deerislandrestoration/home. Accessed 15 Jan 2021

Bockelmann A, Bakker J, Neuhaus R, Lage L (2002) The relation between vegetation zonation, elevation and inundation frequency in a Wadden Sea salt marsh. Aquatic Botany 73:211221.

Broome S, Seneca E, Woodhouse W (1988) Tidal salt marsh restoration. Aquatic Botany 32:122.

Burger J (2017) Avian Resources of the Northern Gulf of Mexico. In: Ward C (ed) Habitats and Biota of the Gulf of Mexico: Before the Deepwater Horizon Oil Spill: Volume 2: Fish Resources, Fisheries, Sea Turtles, Avian Resources, Marine Mammals, Diseases and Mortalities. Springer, New York, pp 1353-1488

Caceres M, Legendre P (2009) Associations between species and groups of sites: indices and statistical inference. Ecology 90: 3566-3574

Cammen L (1975) Accumulation rate and turnover time of organic carbon in a salt marsh sediment. Limnology and Oceanography 20:1012-1015.

Caratti J (2006) Point intercept sampling method. USDA Forest Service Gen. Tech.

Choi Y, Wang Y, Hsieh Y, Robinson L (2001) Vegetation succession and carbon sequestration in a coastal wetland in northwest Florida: Evidence from carbon isotopes. Global Biogeochemical Cycles 15:311-319.

Clewell A (1985) Guide to the vascular plants of the Florida panhandle. Florida State University Press, University Presses of Florida. 
Correll D, Johnston M (1970) Manual of the vascular plants of Texas. Texas Research

$491 \quad$ Foundation.

492 Craft C, Broome S, Campbell C (2002) Fifteen years of vegetation and soil development after 493 brackish-water marsh creation. Restoration Ecology 10:248-258.

494 Craft C, Megonigal P, Broome S, Stevenson J, Freese R, Cornell J, Zheng L, Sacco J (2003) The 495 Pace of Ecosystem Development of Constructed Spartina aterniflora Marshes. Ecological 496 Applications 13:1417-1432.

497 Earhart H, Garbish E (1983) Habitat development utilizing dredged material at Barren Island, 498 Dorchester County, Maryland. Wetlands 3:108-119.

499 Ebbets A, Lane D, Dixon P, Hollweg T, Huisenga M, Gurevitch J (2019) Using meta-analysis to 500 develop evidence-based recovery trajectories of vegetation and soils in restored wetlands in the northern Gulf of Mexico. Estuaries and Coasts 43:1692-1710.

Eleuterius L (1972) The Marshes of Mississippi. In: Christmas J (ed) Cooperative Gulf of Mexico estuarine inventory and study Mississippi. Gulf Coast Research Laboratory. pp 149$512 \quad$ Applied Vegetation Science 11:335-344.

513 Gerhardt Smith J, McDonald J, Rees S, Lovelace N (2015) Deer Island aquatic ecosystem 514 restoration project. EWN Technical Notes Collection. ERDC TN-EWN-15-2, U.S. Army 515 Engineer Research and Development Center, Vicksburg, MS.

516 Greenberg J (1956) The measurement of linguistic diversity. Language 32:109-115.

517 Herbert E, Marton J, Craft C (2016) Tidal Wetland Restoration. In: Vepraskas M, Craft C (eds)

518 Wetland Soils: Genesis, Hydrology, Landscapes, and Classification, $2^{\text {nd }}$ ed, Taylor and $519 \quad$ Francis, pp 447-468. 
Hunter A, Morris N, Lafabrie C, Cebrian J (2008) Effects of nutrient enrichment on Distichlis spicata and Salicornia bigelovii in a marsh salt pan. Wetlands 28:760-775.

Johnson A (1997) Rates of vegetation succession on a coastal dune system in northwest Florida.

523 Journal of Coastal Research 13:373-384.

524 Kirwan M, Megonigal P (2013) Tidal wetland stability in the face of human impacts and sealevel rise. Nature 504:53-60.

Klijn F, Witte J (1999) Eco-hydrology: Groundwater flow and site factors in plant ecology. Hydrogeology Journal 7:65-77.

Lang M (2012) Post-Construction Assessment of Saltmarsh Habitat on Deer Island, Biloxi,

529 Mississippi. MS Thesis, University of South Alabama.

LaSalle M (1996) Assessing the functional level of a constructed intertidal marsh in Mississippi. US Army Corps of Engineers, Waterways Experiment Station, Vicksburg, MS.

LaSalle M, Landin M, Sims J (1991) Evaluation of the flora and fauna of a Spartina alterniflora marsh established on dredged material in Winyah Bay, South Carolina. Wetlands 11:191208.

Luken J (1990) Directing ecological succession. Chapman and Hall, London.

Mavrodi O, Jung C, Eberly J, Hendry S, Namjilsuren S, Biber P, Indest K, Mavrodi D (2018) Rhizosphere microbial communities of Spartina alterniflora and Juncus roemerianus from restored and natural tidal marshes on Deer Island, Mississippi. Frontiers in Microbiology 9:3049.

MDMR - Mississippi Department of Marine Resources (2010) Deer Island Restoration Project. http://www.dmr.state.ms.us/Coastal-Ecology/GEMS/deer-island-restoration.htm). Accessed 3 August 2011

Mendelssohn I, Morris J (2002) Eco-Physiological Controls on the Productivity of Spartina alterniflora Loisel. In Weinstein M, Kreeger D (eds) Concepts and Controversies in Tidal Marsh Ecology. Kluwer Academic Publishers, Dordrecht. Pp 59-80

Mitsch W, Wilson R (1996) Improving the success of wetland creation and restoration with know-how, time, and self-design. Ecological Applications 6:77-83.

Mossman H, Davy A, Grant A (2012) Does managed coastal realignment create saltmarshes with 'equivalent biological characteristics' to natural reference sites? J Applied Ecology 49: 1446-1456. 
Murphy N (2020) Vegetative Community and Health Assessment of a Constructed JuncusDominated Salt Marsh in the Northern Gulf of Mexico. MS Thesis, University of Southern Mississippi

Oksanen J, Blanchet F, Friendly M, Kindt R, Legendre P, McGlinn D, Minchin P, O’Hara R, Simpson G, Solymos P, Stevens M, Szoecs E, Wagner H (2018) vegan: Community Ecology Package.

Packham J, Willis A (1997) Ecology of dunes, salt marsh and shingle. University Press, Cambridge.

Peet R (1974) The measurement of species diversity. Annual Review of Ecology and Systematics 5:285-307.

Petchey O, Gaston K (2006) Functional diversity: back to basics and looking forward. Ecology Letters 9:741-758.

Peterson M, Waggy G, Woodrey M (2007) Grand Bay National Estuarine Research Reserve: An Ecological Characterization. Grand Bay National Estuarine Research Reserve, Moss Point, Mississippi

Radford A, Ahles H, Bell C (1983) Manual of the vascular flora of the Carolinas. University of North Carolina Press.

R Core Team (2018) R: A language and environment for statistical computing. R Foundation for Statistical Computing, Vienna, Austria.

Roth W, Dinicola W, Mears W, Merritts T, Keith D, Ramseur G (2012) Beneficial Use at Deer Island: A Decade of Design and Implementation. Proceedings of the Western Dredging Association (WEDA XXXII) Technical Conference. San Antonio, Texas, June 10-13, 2012.

Silliman B, Schrack E, He Q, Cope R, Santoni A, van der Heide T, Jacobi R, Jacobi M, van de Koppel J (2015) Facilitation shifts paradigms and can amplify coastal restoration efforts. Proceedings of the National Academy of Sciences 112:14295-14300.

Silvestri S, Defina A, Marani M (2005) Tidal regime, salinity and salt marsh plant zonation. Estuarine, Coastal and Shelf Science 62:119-130.

Sparks E, Cebrian J, Biber P, Sheehan K, Tobias C (2013) Cost-effectiveness of two small-scale salt marsh restoration designs. Ecological Engineering 53:250-256.

Sparks E, Cebrian J, Tobias C, May C (2015) Groundwater nitrogen processing in northern Gulf of Mexico restored marshes. Journal of Environmental Management 150:206-215. 
582 Stedman S, Dahl T (2008) Status and trends of wetlands in the coastal watersheds of the eastern $583 \quad$ United States 1998 to 2004. National Oceanic and Atmospheric Administration, National 584 Marine Fisheries Service, and U.S. Department of the Interior, Fish and Wildlife Service, 585 Washington, DC.

586 Streever W (2000) Spartina alterniflora marshes on dredged material: a critical review of the ongoing debate over success. Wetlands Ecology and Management 8:295-316.

Taddeo S, Dronova I (2018) Indicators of vegetation development in restored wetlands. Ecological Indicators 94:454-467.

Taniguchi M (1996) A comparison of natural and restored salt marsh vegetation and soil characteristics. MS Thesis, San Jose State University.

Turner R (1990) Landscape development and coastal wetland losses in the northern Gulf of

594 Turner R (1997) Wetland loss in the northern Gulf of Mexico: multiple working hypothesis.

595 Estuaries 20:1-13.

596 USDA - United States Department of Agriculture (2010) National plant materials manual, 4th 597 ed. United States Department of Agriculture, Natural Resources Conservation Service.

Walker L, Walker J, Hobbs R (2007) Linking restoration and ecological succession. SpringerVerlag, New York.

601 Complex, Texas. Wetlands 4:75-86.

602 Weisberg S, Whalen R, Lotrich V (1981) Tidal and diurnal influence on food consumption of a 603 salt marsh killifish Fundulus heteroclitus. Marine Biology 61:243-246.

604 Wickham H (2016) ggplot2: Elegant graphics for data analysis. Springer-Verlag New York.

605 Woerner L, Hackney C (1997) Distribution of Juncus roemerianus in North Carolina tidal 606 marshes: the importance of physical and biotic variables. Wetlands 17:284-291.

607 Woodhouse W (1979) Building salt marshes along the coasts of the continental United States.

608 Coastal Engineering Research Center Vicksburg, MS.

609 Wright J, Ramseur G, Leggett A (2013) Muck to Marshes Tidal Marsh Restoration using 610 Beneficial Use of Dredge Materials - A manual for volunteer monitors. Department of 611 Marine Resources, Biloxi, MS. 
612 Wu W, Biber P, Bethel M (2017) Thresholds of sea-level rise rate and sea-level rise acceleration 613 rate in a vulnerable coastal wetland. Ecology and Evolution 7:10890-10903.

614 Wu W, Biber P, Mishra D, Ghosh S (2020) Sea-level rise thresholds for stability of salt marshes 615 in a riverine versus a marine dominated estuary. Science of The Total Environment. 718 : $616 \quad 137181$

617 Zedler J, Callaway J (1999) Tracking wetland restoration: do mitigation sites follow desired 618 trajectories? Restoration Ecology 7:69-73.

619 Zedler J, Callaway J (2000) Evaluating the progress of engineered tidal wetlands. Ecological 620 Engineering 15:211-225.

621 Zedler J, (2000) Progress in wetland restoration ecology. Trends in Ecology and Evolution 622 15:402-407.

623

624 


\section{Tables}

626

627 Table 1. Summary of sampling conducted at each site over the six seasons observed in this study.

Spring Fall Spring Fall Spring Fall

Quadrat transects
Point-intercept

\begin{tabular}{rrrrrr}
2017 & 2017 & 2018 & 2018 & 2019 & 2019 \\
\hline 2 & 2 & 2 & 2 & 2 & 2
\end{tabular}

transects

Biomass cores taken

Elevation Points

$\begin{array}{cccccc}0 & 3 & 3 & 3 & 3 & 0 \\ \text { Yes } & \text { Yes } & \text { Yes } & \text { Yes } & \text { Yes } & \text { No } \\ & \text { Yes } & & \text { Yes } & & \end{array}$

630 Table 2. Mean and range of elevation at constructed and reference salt marsh sites on Deer

631 Island, MS, measured in meters above mean sea level (MAMSL). Superscripts denote significant 632 groupings $(\mathrm{p}<0.05)$ calculated by Tukey's HSD.

633

\begin{tabular}{lccc} 
Site & Mean Elevation (MAMSL) & Range (MAMSL) & $\mathrm{n}$ \\
\hline $2+$ yr constructed $^{\mathrm{b}}$ & 0.54 & 0.35 & 56 \\
10+ yr constructed $^{\mathrm{a}}$ & 0.76 & 0.80 & 55 \\
$100+\mathrm{yr}^{\mathrm{r}}$ reference $^{\mathrm{c}}$ & 0.27 & 0.50 & 54
\end{tabular}

634 
635 Table 3. Species list and percent occurrence of salt marsh and dune vegetation observed from

636 quadrat (Q) and point-intercept (PI) sampling at two constructed marshes and a natural reference

637 marsh across four sampling seasons.

\begin{tabular}{|c|c|c|c|c|c|c|}
\hline \multirow[b]{2}{*}{ Species } & \multicolumn{2}{|c|}{$2+\mathrm{yr}$} & \multicolumn{2}{|c|}{$10+\mathrm{yr}$} & \multicolumn{2}{|c|}{$100+\mathrm{yr}$} \\
\hline & Q & PI & Q & PI & Q & PI \\
\hline Andropogon virginicus $\mathrm{L}$. & & & 3 & $<1$ & & \\
\hline Baccharis halimifolia $\mathrm{L}$. & $<1$ & $<1$ & 2 & 2 & & \\
\hline Cyperus spp. & & & 1 & $<1$ & & \\
\hline Distichlis spicata (L.) Greene & 9 & 4 & 8 & 7 & & 1 \\
\hline Eragrostis secundiflora J. Presl & & & 2 & 3 & & \\
\hline Eupatorium capillifolium (Lam.) Small & & $<1$ & 1 & $<1$ & & \\
\hline Fimbristylis castanea (Michx.) Vahl & & & 5 & 2 & & \\
\hline Heterotheca subaxillaris (Lam.) Britton \& Rusby & & & & $<1$ & & \\
\hline Hydrocotyle bonariensis Comm. Ex Lam. & & & 1 & 8 & & \\
\hline Imperata cylindrica (L.) P. Beauv. & & & & $<1$ & & \\
\hline Ipomoea imperati (Vahl) Griseb. & & $<1$ & $<1$ & $<1$ & & \\
\hline Iva frutescens L. & & $<1$ & 2 & 1 & & \\
\hline Iva imbricata Walter & & & & $<1$ & & \\
\hline Juncus roemerianus Scheele & 1 & 1 & 2 & 2 & 36 & 37 \\
\hline Limonium carolinianum (Walter) Britton & & & & $<1$ & & \\
\hline Phyla nodiflora (L.) Greene & & & & $<1$ & & \\
\hline Panicum amarum Elliott & 5 & 2 & & $<1$ & & \\
\hline Panicum repens $\mathrm{L}$. & $<1$ & 1 & & & & \\
\hline Paspalum distichum $\mathrm{L}$. & 6 & 2 & 3 & $<1$ & & \\
\hline Physalis angustifolia Nutt. & & & & $<1$ & & \\
\hline Polypremum procumbens L. & & & $<1$ & $<1$ & & \\
\hline Proserpinaca intermedia Mack. & & & & $<1$ & & \\
\hline Ruppia maritima $\mathrm{L}$. & & 2 & & & & \\
\hline Sarcocornia perennis (Mill.) A.J. Scott & & & & $<1$ & & \\
\hline Schizachyrium maritimum (Chapm.) Nash & & $<1$ & & 2 & & \\
\hline $\begin{array}{r}\text { Schoenoplectus americanus (Pers.) Volkart ex } \\
\text { Schinz \& R. Keller }\end{array}$ & 1 & $<1$ & 1 & $<1$ & & \\
\hline Schoenoplectus robustus (Pursh) M.T. Strong & & $<1$ & & $<1$ & & $<1$ \\
\hline Sesbania herbacea (Mill.) McVaugh & & & $<1$ & $<1$ & & \\
\hline Sesuvium portulacastrum (L.) L. & $<1$ & 1 & $<1$ & & & \\
\hline Solidago sempervirens L. & & & 4 & 4 & & \\
\hline Spartina alterniflora Loisel. & 63 & 75 & 34 & 16 & 62 & 61 \\
\hline Spartina patens (Aiton) Muhl. & 13 & 9 & 29 & 42 & 1 & $<1$ \\
\hline Symphyotrichum tenuifolium (L.) G.L. Nesom & & & 1 & & & \\
\hline Uniola paniculata $\mathrm{L}$. & 1 & $<1$ & & & & \\
\hline Vigna luteola (Jacq.) Benth & $<1$ & 1 & 2 & 4 & & \\
\hline TOTAL & 100 & 100 & 100 & 100 & 100 & 100 \\
\hline
\end{tabular}


641 Table 4. Diversity indices and species richness calculated from quadrat (Q) and point-intercept

642 (PI) sampling at two constructed marshes and a natural reference marsh across five sampling 643 seasons.

644

645

\begin{tabular}{|c|c|c|c|c|c|c|}
\hline & \multicolumn{2}{|c|}{ Shannon-Wiener $\left(H^{\prime}\right)$} & \multicolumn{2}{|c|}{ Simpson's (D) } & \multicolumn{2}{|c|}{ Richness } \\
\hline & $\mathrm{Q}$ & PI & $\mathrm{Q}$ & PI & $\mathrm{Q}$ & PI \\
\hline \multicolumn{7}{|l|}{ Spring 2017} \\
\hline $2+\mathrm{yr}$ constructed & 1.47 & - & 0.68 & - & 10 & - \\
\hline $10+y r$ constructed & 2.24 & - & 0.85 & - & 19 & - \\
\hline $100+$ yr reference & 0.75 & - & 0.51 & - & 3 & - \\
\hline \multicolumn{7}{|l|}{ Fall 2017} \\
\hline $2+\mathrm{yr}$ constructed & 0.78 & 0.76 & 0.36 & 0.35 & 7 & 5 \\
\hline $10+y r$ constructed & 1.65 & 1.60 & 0.69 & 0.68 & 16 & 11 \\
\hline $100+$ yr reference & 0.68 & 0.69 & 0.48 & 0.48 & 3 & 3 \\
\hline \multicolumn{7}{|l|}{ Spring 2018} \\
\hline $2+\mathrm{yr}$ constructed & 0.67 & 0.84 & 0.33 & 0.36 & 4 & 7 \\
\hline $10+y r$ constructed & 0.97 & 1.80 & 0.54 & 0.74 & 9 & 21 \\
\hline $100+y r$ reference & 0.55 & 0.69 & 0.36 & 0.42 & 2 & 3 \\
\hline \multicolumn{7}{|l|}{ Fall 2018} \\
\hline $2+\mathrm{yr}$ constructed & 1.37 & 1.44 & 0.69 & 0.59 & 4 & 14 \\
\hline $10+y r$ constructed & 1.63 & 2.42 & 0.77 & 0.85 & 9 & 25 \\
\hline $100+y r$ reference & 1.08 & 0.89 & 0.65 & 0.56 & 2 & 2 \\
\hline \multicolumn{7}{|l|}{ Spring 2019} \\
\hline $2+\mathrm{yr}$ constructed & 1.62 & 1.24 & 0.76 & 0.55 & 8 & 10 \\
\hline $10+\mathrm{yr}$ constructed & 1.74 & 2.22 & 0.78 & 0.83 & 8 & 20 \\
\hline $100+$ yr reference & 1.14 & 0.89 & 0.67 & 0.52 & 3 & 5 \\
\hline
\end{tabular}

646 


\section{$647 \quad$ Figures}

648 Fig. 1 Location of transects sampled on Deer Island, MS with constructed salt marshes of

649 differing ages and a natural reference marsh outlined. 1: DIMR2, 2+ years old. 2: DIMR1, 10+

650 years old. 3: REF is the natural reference site, 100+ years old

651 Fig. 2 Species richness by season at two constructed marshes of differing ages and a natural

652 reference marsh measured with quadrat (1) and point-intercept (2) sampling. The total percent

653 coverage of vegetation at the constructed sites and reference marsh using (4) quadrat and (5)

654 point-intercept sampling, respectively

655 Fig. 3 Non-metric multidimensional scaling plot $(\mathrm{k}=2$, Stress $=0.08)$ of vegetative species

656 abundances cover grouped for all five sampling seasons at constructed sites and natural reference

657 site at Deer Island, MS. The larger dots are the centroids with 95\% confidence interval ellipses

658 for each group

659 
660

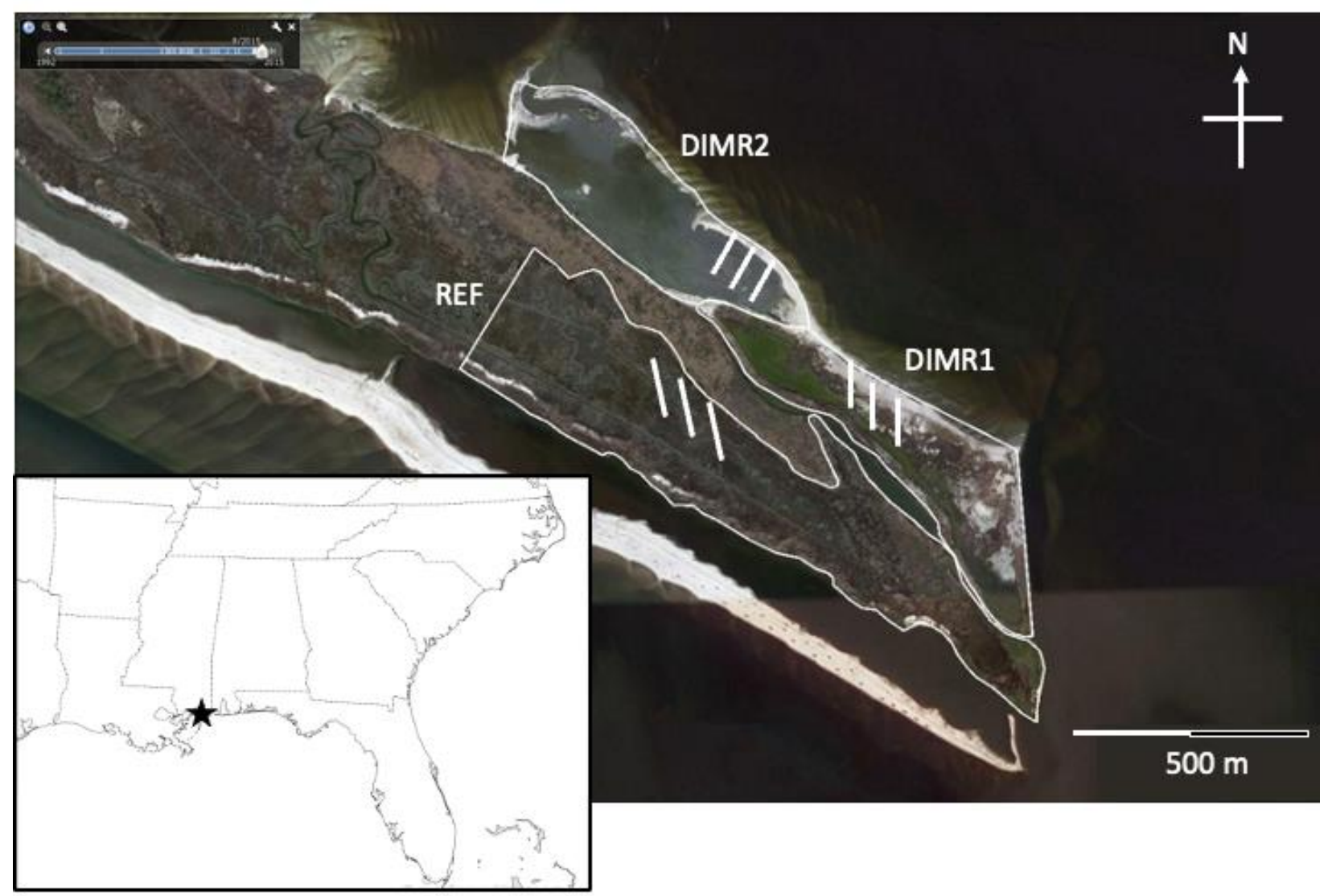

Figure 1

661

662 
663
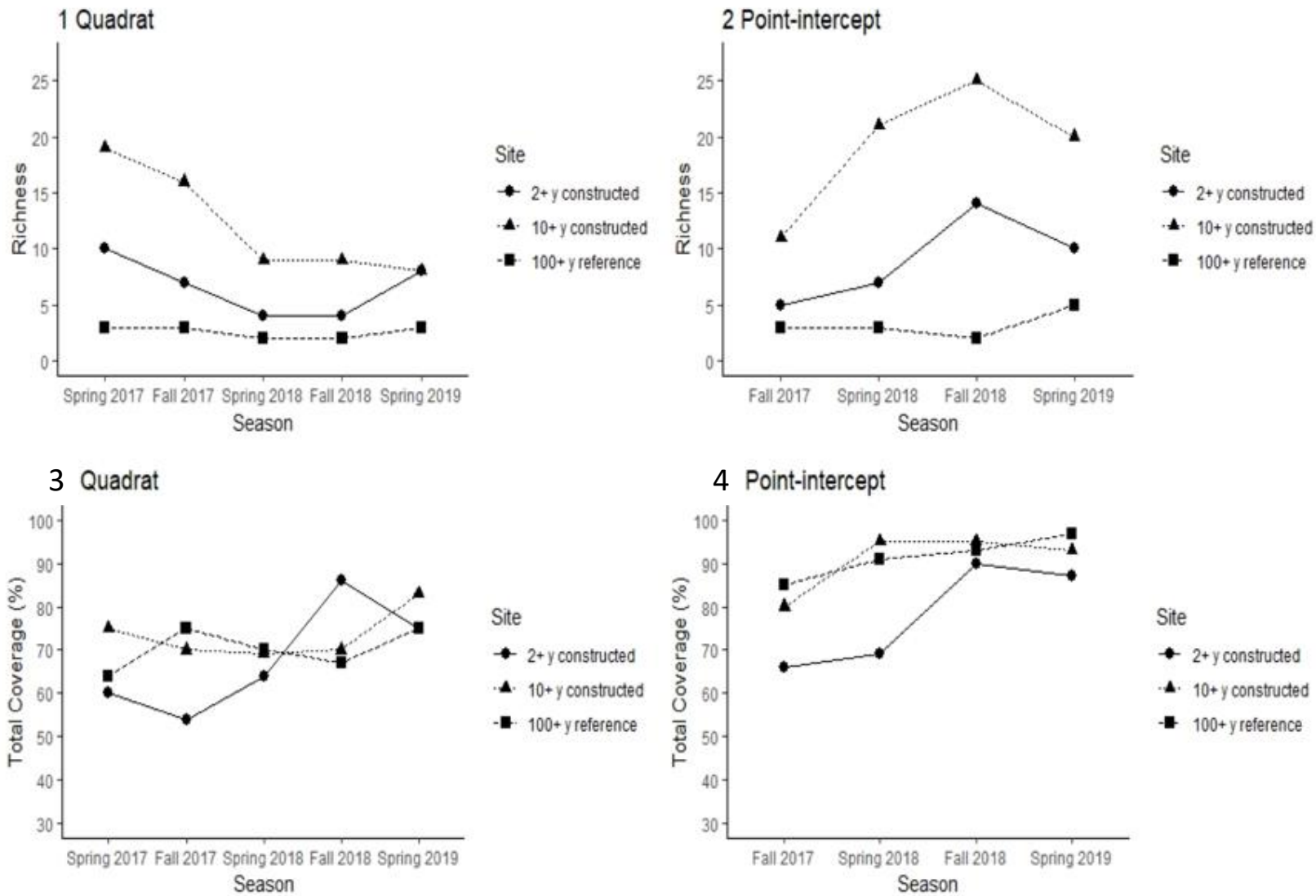

664

665

666

Figure 2 
667

668

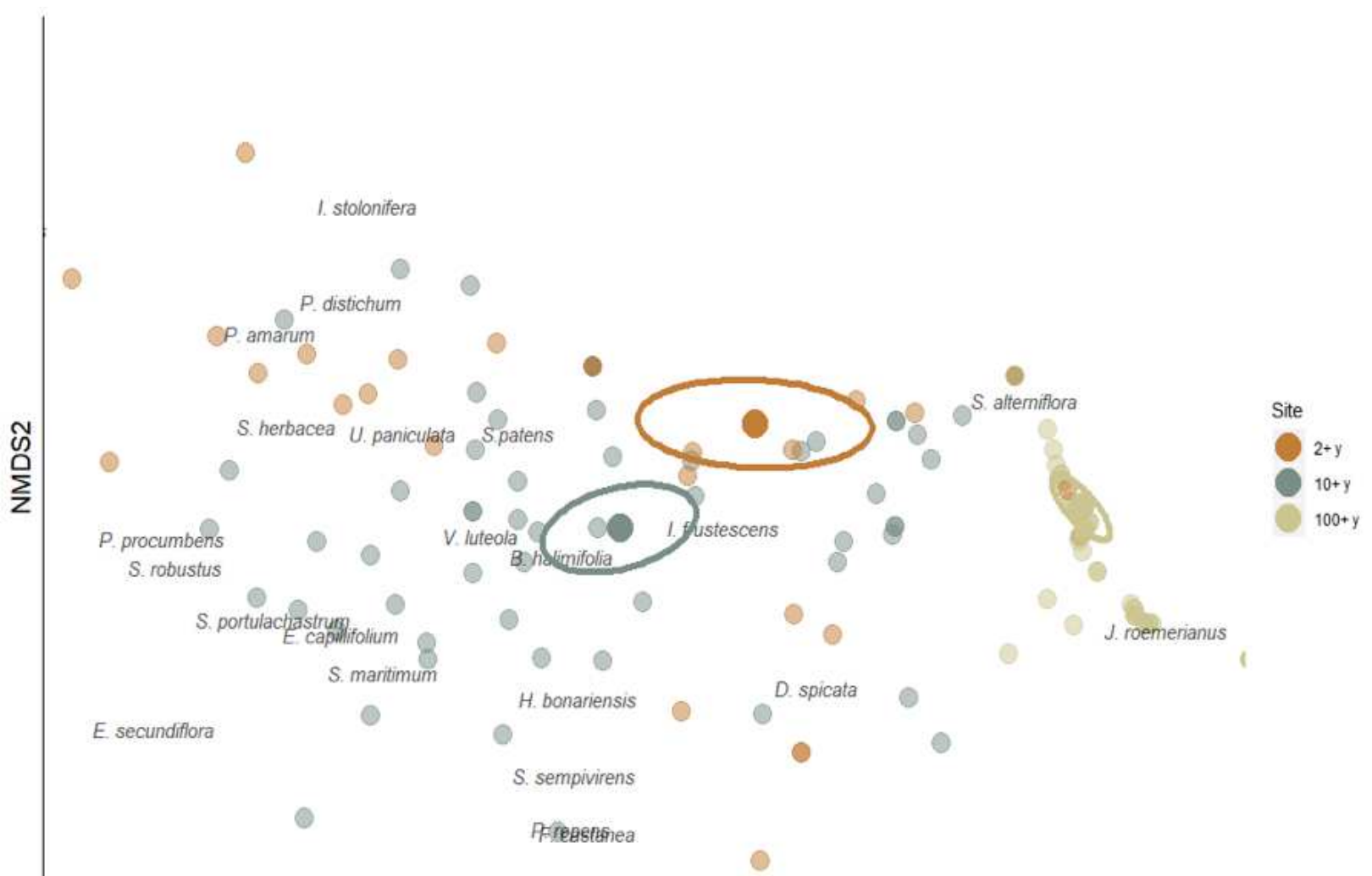

671

672 


\section{Supplementary Information}

674

675

676

677

678

679

680

681

682 Table S2. Results of ANOSIM comparisons of Bray-Curtis dissimilarity across two constructed

683 marshes and a natural reference marsh. * Denotes significant difference at alpha $=0.05$.

684

685

686

Table S1. One-Way ANOVA table for mean elevation (MAMSL) by site $(\mathrm{n}=3)$.

\begin{tabular}{lccccc} 
Source & $d f$ & SS & MS & $F$ & $p$ \\
\hline Site & 2 & 6.638 & 3.319 & 239.4 & $<0.001$ \\
Residuals & 162 & 2.246 & 0.014 & &
\end{tabular}

\begin{tabular}{ccc} 
Comparisons & Distance $(\mathrm{R})$ & Significance \\
\hline $2+\mathrm{y} \times 10+\mathrm{y}$ & 0.11 & $<0.001^{*}$ \\
$2+\mathrm{y} \times 100+\mathrm{y}$ & 0.21 & $<0.001^{*}$ \\
$10+\mathrm{y} \times 100+\mathrm{y}$ & 0.39 & $<0.001^{*}$
\end{tabular}


687 Table S3. Results of indicator species analysis of salt marsh plants at the $2+\mathrm{yr}$ constructed site 688 within low and intermediate elevation zones. 1 denotes an association of a species with the 689 respective elevation zone at the $2+$ yr constructed site. $*$ denotes a significant association of a 690 species with the respective elevation zone at the $2+\mathrm{yr}$ constructed site.

691

\begin{tabular}{lcccc}
\multicolumn{1}{c}{ Species } & 0 - 0.54 MAMSL & $0.54-0.76$ MAMSL & IV & $p$ \\
\hline Spartina patens & 0 & 1 & 0.59 & $<0.01^{*}$ \\
Paspalum distichum & 0 & 1 & 0.34 & 0.23 \\
Vigna luteola & 1 & 0 & 0.27 & 0.36 \\
Baccharis halimifolia & 1 & 0 & 0.21 & 0.42 \\
Distichlis spicata & 0 & 1 & 0.33 & 0.35 \\
Schoenoplectus americanus & 1 & 0 & 0.24 & 0.47 \\
Spartina alterniflora & 1 & 0 & 0.76 & $<0.01^{*}$ \\
Panicum amarum & 0 & 1 & 0.43 & 0.14 \\
Panicum repens & 0 & 1 & 0.25 & 0.51 \\
Sesuvium portulacastrum & 0 & 1 & 0.35 & 0.14 \\
Juncus roemerianus & 0 & 1 & 0.33 & 0.33 \\
Uniola paniculata & 0 & 1 & 0.17 & 1.00
\end{tabular}

692

693 
Table S4. Results of indicator species analysis of salt marsh plants at the 10+ yr constructed site within low, intermediate, and high elevation zones. 1 denotes an association of a species with the respective elevation zone at the $10+$ yr constructed site. * denotes a significant association of a species with the respective elevation zone at the $10+\mathrm{yr}$ constructed site.

\begin{tabular}{lccccc}
\multicolumn{1}{c}{ Species } & - 0.54 MAMSL & $0.54-0.76$ MAMSL & $>0.76$ MAMSL & IV & $p$ \\
\hline Spartina patens & 0 & 1 & 0 & 0.52 & 0.52 \\
Paspalum distichum & 0 & 1 & 0 & 0.20 & 0.77 \\
Vigna luteola & 0 & 0 & 1 & 0.55 & $0.04 *$ \\
Baccharis halimifolia & 0 & 0 & 1 & 0.29 & 0.72 \\
Eragrostis secundiflora & 0 & 0 & 1 & 0.45 & 0.05 \\
Sesbania herbacea & 0 & 0 & 1 & 0.24 & 0.51 \\
Cyperus spp. & 0 & 0 & 1 & 0.30 & 0.34 \\
Hydrocotyle bonariensis & 0 & 1 & 0 & 0.28 & 0.70 \\
Iva frutescens & 0 & 1 & 0 & 0.34 & 0.21 \\
Distichlis spicata & 1 & 0 & 0 & 0.69 & $<0.001^{*}$ \\
Schoenoplectus americanus & 0 & 1 & 0 & 0.21 & 0.46 \\
Schoenoplectus robustus & 1 & 0 & 0 & 0.33 & 0.13 \\
Eragrostis secundiflora & 0 & 0 & 1 & 0.39 & 0.15 \\
Fimbristylis castanea & 0 & 1 & 0 & 0.35 & 0.43 \\
Spartina alterniflora & 1 & 0 & 0 & 0.68 & $<0.01^{*}$ \\
Panicum amarum & 0 & 1 & 0 & 0.21 & 0.46 \\
Sesuvium portulacastrum & 0 & 1 & 0 & 0.21 & 0.48 \\
Juncus roemerianus & 0 & 1 & 0 & 0.30 & 0.20 \\
Solidago sempivirens & 0 & 1 & 0 & 0.27 & 0.83 \\
Schizachyrium maritimum & 0 & 1 & 0 & 0.20 & 0.87 \\
Symphyotrichum tenuifolium & 0 & 1 & 0 & 0.21 & 0.48 \\
Polypremum procumbens & 0 & 0 & 1 & 0.17 & 1.00 \\
Ipomea stolonifera & 0 & 0 & 1 & 0.17 & 1.00
\end{tabular}


Table S5. Results of indicator species analysis of salt marsh plants at the $100+\mathrm{y}$ natural reference site within low and intermediate elevation zones. 1 denotes an association of a species with the respective elevation zone at the $100+$ y natural reference site. $*$ denotes a significant association of a species with the respective elevation zone at the $100+$ yr constructed site.

\begin{tabular}{lcccc}
\multicolumn{1}{c}{ Species } & $0-0.54$ MAMSL & $0.54-0.76$ MAMSL & IV & $p$ \\
\hline Distichlis spicata & 0 & 1 & 0.30 & $0.04^{*}$ \\
Spartina alterniflora & 1 & 0 & 0.95 & 0.29 \\
Juncus roemerianus & 1 & 0 & 0.79 & 0.89
\end{tabular}




\section{Figures}

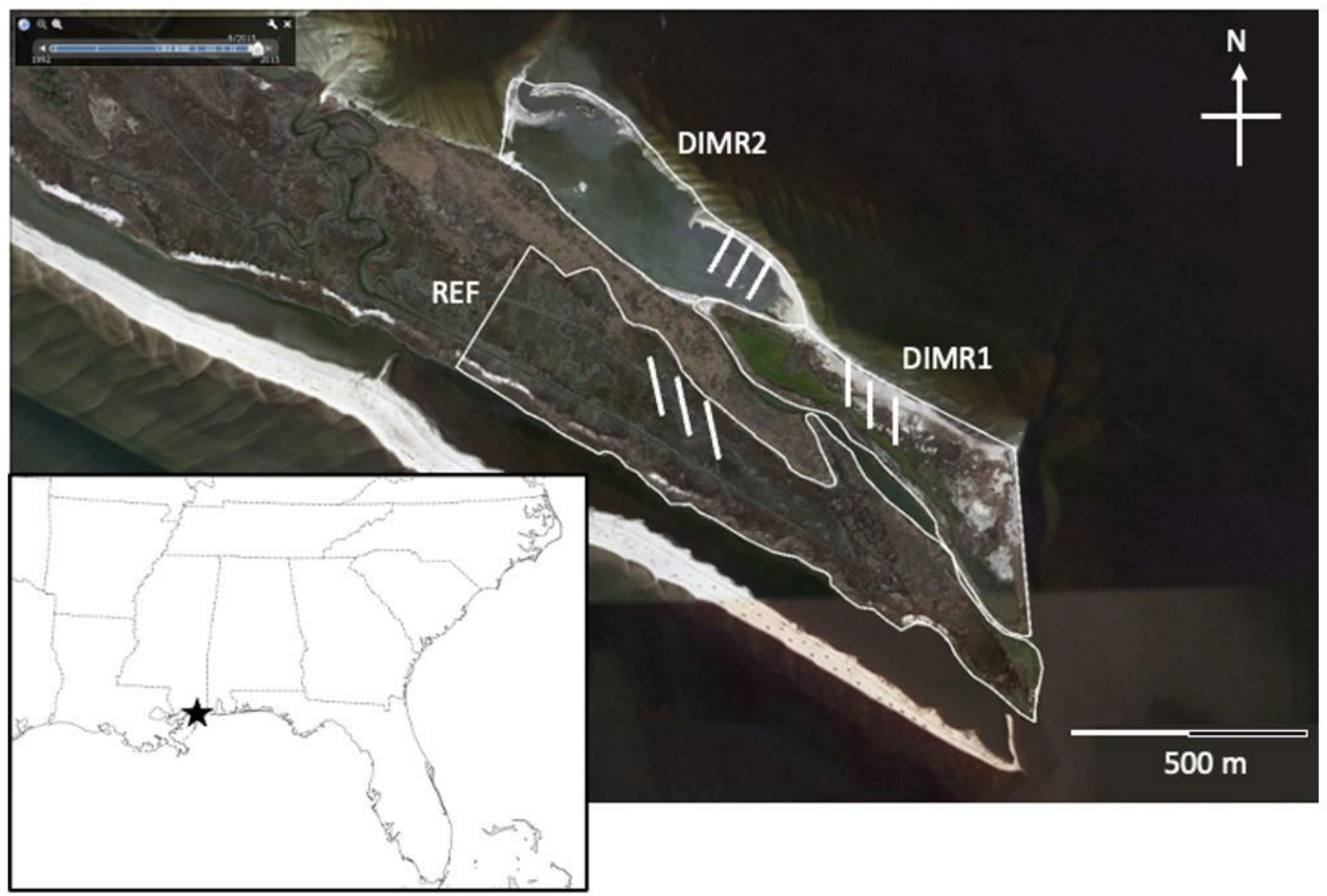

\section{Figure 1}

Location of transects sampled on Deer Island, MS with constructed salt marshes of differing ages and a natural reference marsh outlined. 1: DIMR2, 2+ years old. 2: DIMR1, 10+ years old. 3: REF is the natural reference site, $100+$ years old Note: The designations employed and the presentation of the material on this map do not imply the expression of any opinion whatsoever on the part of Research Square concerning the legal status of any country, territory, city or area or of its authorities, or concerning the delimitation of its frontiers or boundaries. This map has been provided by the authors. 

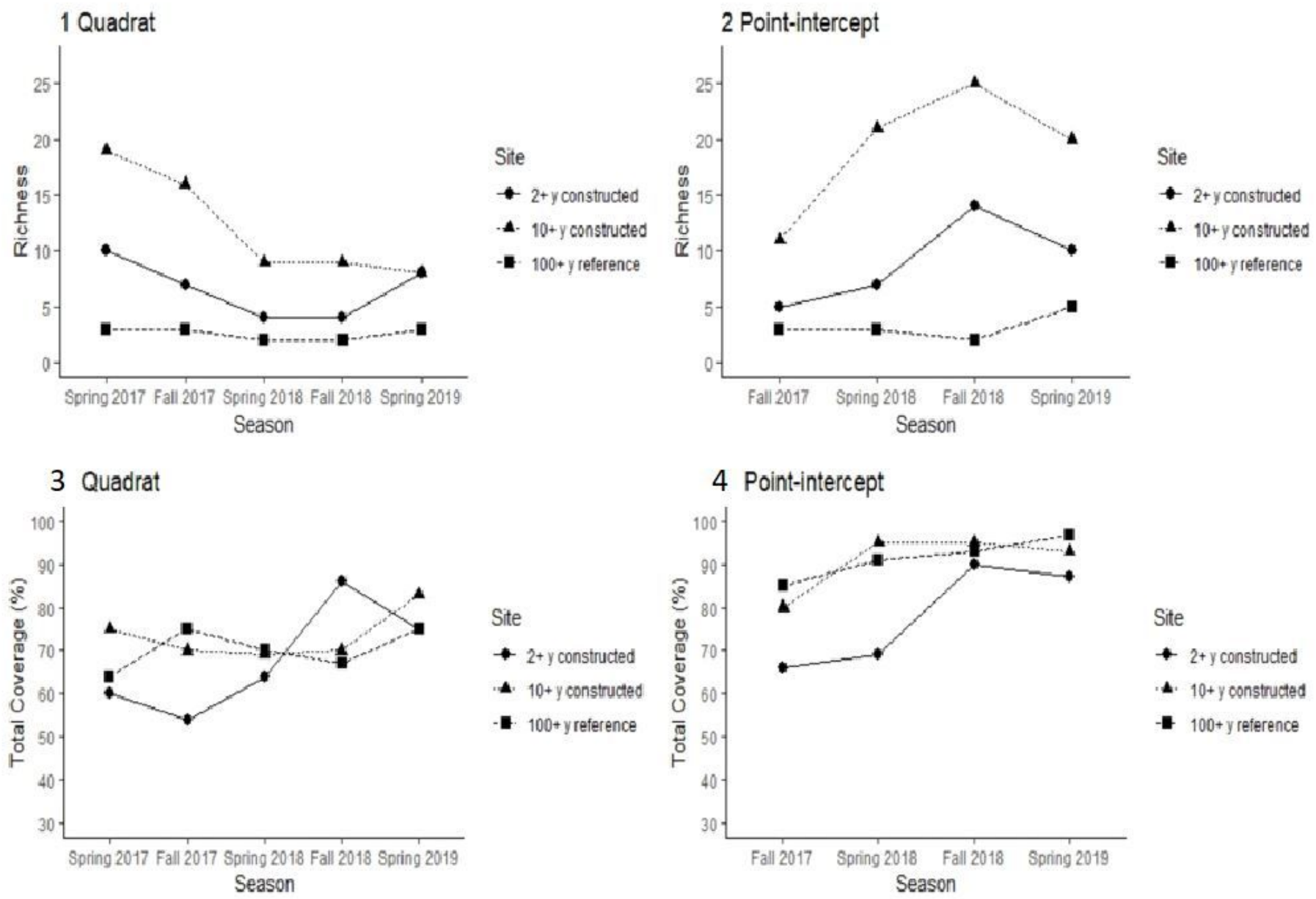

Figure 2

Species richness by season at two constructed marshes of differing ages and a natural reference marsh measured with quadrat (1) and point-intercept (2) sampling. The total percent coverage of vegetation at the constructed sites and reference marsh using (4) quadrat and (5) point-intercept sampling, respectively 


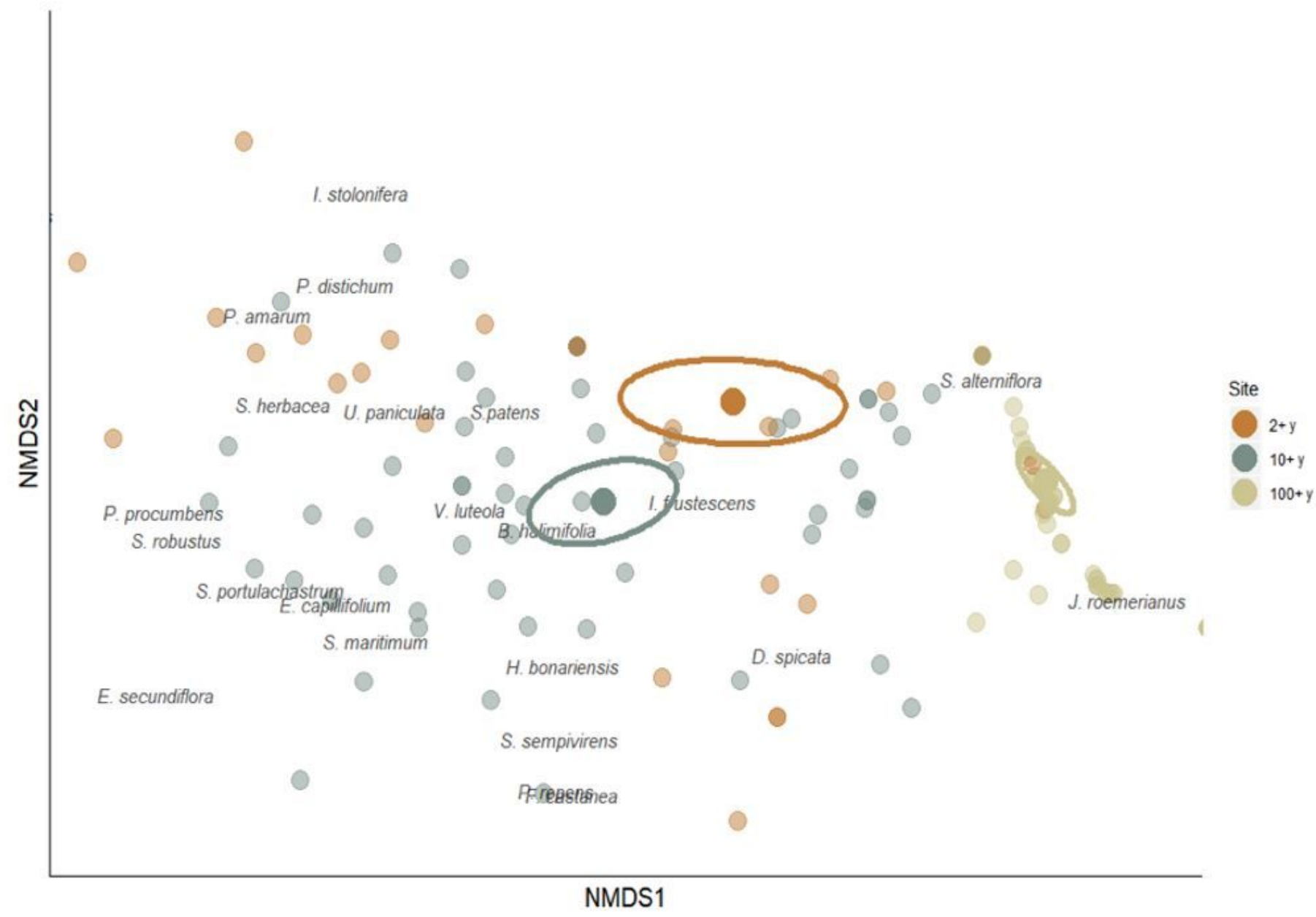

Figure 3

Non-metric multidimensional scaling plot $(\mathrm{k}=2$, Stress $=0.08)$ of vegetative species abundances cover grouped for all five sampling seasons at constructed sites and natural reference site at Deer Island, MS. The larger dots are the centroids with $95 \%$ confidence interval ellipses for each group

\section{Supplementary Files}

This is a list of supplementary files associated with this preprint. Click to download.

- Supplementarylnformation.docx 